ORIENT Volume 50, 2015

\title{
The $\bar{I} n g \check{u} \overline{~ i n ~ I r a n ~ u n d e r ~ t h e ~ I l k h a n a t e ~}$
}

\author{
Sanae TAKAGI
}

The Society for Near Eastern Studies in Japan (NIPPON ORIENTO GAKKAI) 


\title{
The $\overline{I n} \check{g} \bar{u}$ in Iran under the Ilkhanate
}

\author{
Sanae TAKAGI*
}

\begin{abstract}
This paper attempts to analyze the nature, formation, and administration of the $\overline{i n g} \bar{u} \overline{\text { in }}$ Iran under the Ilkhanate. The term $\bar{i} n g \bar{u}$, derived from the Mongolian word emčü, refers to the private lands and subjects of Ilkhan, other Hülegüids, or other Chinggisids. During Abaya Qan's reign, the influence of Jö̌̌i, Ča aratai, and Ögödei families in Iran gradually fell and the $\bar{\imath} n g \bar{u}$ of the Hülegüids began to increase. Although an Ilkhan's $\bar{i} n g \bar{u}$ formed during his reign usually passed to the next Ilkhan, the Ilkhan's sons had authority over the $\bar{i} n g \bar{u}$ that originated from before the Ilkhan's enthronement. In contrast to $\bar{i} n g \bar{u}$, the term dalāy was applied to dīwāni property administered by the supreme dīwān.
\end{abstract}

Keywords: private property, īnjū (emčü), khāsșa, Ilkhanate, Iran

\section{Introduction}

The Ilkhanate was founded in Iran, roughly corresponding to the regions between the Amu river and the Euphrates, by a grandson of Činggis Qan (d. 1227 CE), Hülegü (d. 1265), as the result of his expedition and conquest from 1256 to 1260. This paper analyzes the $\bar{\imath} n g \bar{u} \sim \operatorname{ing} \bar{u}$ in the Ilkhanid period (ca. 1256-after 1335).

The term $\bar{i} n g \bar{u}$, which appears in Persian sources of this period, has been broadly interpreted as referring to the private lands and subjects of the Ilkhan and of his family. ${ }^{1}$ Previous studies, as well as some contemporaneous Persian sources, also point out that the term hạạsa, a term with a long history of usage in Arabic and Persian by that time, gradually came to be used as a synonym of $\bar{i} \check{g} \bar{u}$ in Ilkhanid Iran. ${ }^{2}$

In 1951, Masatsugu Murakami explained that the term $\bar{\imath} n \check{g} \bar{u}$ was derived from the Mongolian

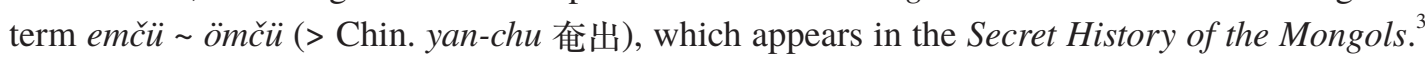
He opposed the view that the term was derived from a similar Mongolian term inje $(\sim$ inji $\sim$ ingji i) "dowry; trousseau; serfs as part of the dowry." According to Murakami, while the term

*Part-time Lecturer, Faculty of Letters, Arts and Sciences, Waseda University

See, e.g., ĞT/Quatremère, 130-131; Minorsky 1943, 24-25; Barthold 1951, 258-260; Honda 1959, 44; Petrushevsky 1960, 240-245; TMEN II, Nr. 670; Petrushevsky 1968, 515; Togan, 1981, 238; Spuler 1985, 273-278; Lambton 1988, 118; Floor 2012, 107-108. Although some believe that $\bar{i} \bar{g} \bar{u}$ in Iran was "the appanages belonging to the relatives of the ruler [i.e., the Ilkhan]" (Schurmann 1956, 330), we find $\bar{\imath} g \check{g} \bar{u}$ belonging to the Ilkhan himself, as shown in this study.

2 E.g., Floor 2012, 107; AM, 40. The general meaning of hāsssa is "private crown lands and other properties, real and moveable, owned or controlled directly by the ruler, as well as all functions, activities, and artifacts pertaining to the ruler, his court, and his family" (Floor 2012). On the Ahbār-i Muğūlān (AM) cited here, see Takagi 2011.

3 SH/Kuribayashi, 176, 180, 296, 312, 416, 442, 462, 570; Murakami 1951, 704-706. This word is translated as ti-ji 梯 己 "private savings; confidential; intimate" in the Chinese glossary of the Secret History of the Mongols, which was added on the right of each row of the text during the Ming period (Murakami 1951, 704, 706-708). Murakami also supposes that M. emčü ömč̈̈ is derived from Old Turkic (Murakami 1951, 713-714). The Turkic term inčü is attested in a Manichaean Turkic text from Xinjiang and a Khotanese document from Dunhuang, both of which belong to the tenth century. See, e.g., Moriyasu 2004, 238.

4 For examples of such a view, see ĞT/Blochet, 215; Petrushevsky 1960, 240; TMEN II, Nr. 670; Buell 2003, 166, the second meaning of "INJE." On the meaning of inje, see Lessing 1960, 411. 
emčü was mostly used in the sense of "belonging to oneself" or "private, personal (properties or possessions)" in the Secret History of the Mongols, its Persian form inğ $\bar{u}$ as used in Persian sources

indicated crown lands and vassals residing in those lands. ${ }^{5}$ Minobu Honda basically agreed with Murakami's view and stated that the term $\bar{i} n g \bar{g}$ as used in the Persian sources means both lands and their inhabitants, belonging to royal families (Honda 1959, 44). The interpretations of the term $\bar{\imath} n g \bar{u}$ presented by Murakami and Honda were shared, albeit in general terms, also by Gerhard Doerfer who defined the term $\overline{i n} \check{g} \bar{u}$ as signifying "crown land" and "immediate vassals (to the Ilkhanid house)" (TMEN II, Nr. 670). These fundamental understandings of the derivations and significations of the term $\bar{i} \check{g} \breve{u}$ will serve as the starting point of discussions in this paper.

Because of limited information on $\bar{\imath} \bar{g} \bar{u}$ in Iran under the Ilkhanate, its actual characteristics and situations remain understood incompletely. Little is known, for example, about who could own $\bar{\imath} n \bar{g} \bar{u}$, of what the owners' authority over $\bar{i} n g \bar{u}$ consisted, how it was formed, and how it was administered. Moreover, it is unclear whether the $\bar{\imath} n g \bar{u}$ of an Ilkhan normally passed to the next Ilkhan or to his descendants (Watabe 1997, 200).

The paper first examines how the term $\bar{i} n g \bar{u}$ is used in the Persian sources from the Ilkhanid period. This examination will clarify different aspects of $\bar{\imath} \check{g} \check{u}$ concept as shared in the milieu of Ilkhanid Iran where those sources were written. Then, the latter part of the paper will discuss about issues concerning formation, development, and administration of the Ilkhan's $\bar{\imath} \check{g} \bar{u}$.

\section{The $\bar{I} n \check{g} \bar{u}$ in Persian Sources of Ilkhanid Iran}

The purpose of the chapter is to analyze how the term $\bar{\imath} n g \bar{u}$ is used in the Persian sources of Ilkhanid Iran, mainly chronicles, in order to clarify the common perception of $\bar{i} \bar{g} \bar{u}$ in those days.

First, what or who could be made $\bar{n} n g \bar{u}$ ? The $\bar{\imath} n \bar{g} \bar{u}$ in the Persian sources of this period consisted of subjects-troops, night guards (kibtawlān), artisans $(\bar{u} z)$, bureaucrats, and other persons-and of real and movable properties, such as provinces (wilāyāt), districts (bulūkāt), cities, villages, lands, parcels of lands, and movable possessions (amlāk wa ašqās wa asbāb) ${ }^{6}$

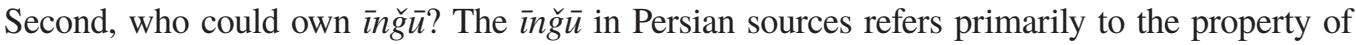
Ilkhan and Hülegüid queens and princes (also princesses). ${ }^{7}$ In addition, the descendants of three sons of Činggis Qan, J̌öči (d. ca. 1225), Ča yatai (d. 1242), and Ögödei Qa'an (r. 1229-1241), also appear as owners of $\bar{\imath}$ ğ $\bar{u}$ properties (AM, 40; ĞT/Rawšan II, 1063; Takagi 2009, 145-146, 148-149). While the

\footnotetext{
5 Murakami 1951, 705; cf. Gong 2009. Murakami holds that the term emčü corresponds to Modern Mongolian ömči "inheritance; property" (see Lessing 1960, 635; SH/de Rachewiltz I, 506). However, "inheritance" is not necessarily the primary meaning of emčü, because emčü property consisted not only of the inheritance but also of things the owner personally acquired, as demonstrated in this study. Kazuhiko Shiraiwa, in a study published in 1988, surveyed how the term $\bar{i} \bar{g} \bar{u}$ was used in the Ğämi 'al-Tawārĭh. As for the derivation and significations of the term, Shiraiwa basically followed Murakami's view in that study.

6 Troops: e.g., ĞT/Rawšan I, 616. Night guards: e.g., ĞT/Rawšan I, 616 (On P. kibtawl [< M. kebte'ül], which was a unit of kesigten [royal guards], see TMEN I, Nr. 322). Artisans: e.g., TW, 127; ǦT/Rawšan II, 1135; AM, 33a (On P. $\bar{u} z$ [< T. uz], see TMEN II, Nr. 593; also in North China under the Mongol Empire, the Chinggisids and the commanders controlled their artisans [e.g., Matsuda 2002]). Bureaucrats: e.g., ĞT/Rawšan II, 1127, 1162. Provinces: e.g., ĞT/ Rawšan I, 775; II, 1167. Districts: e.g., NQ I, 84 (on P. bulūk [< T. bölük], see TMEN II, Nr. 772). Cities: e.g., ĞT/ Quatremère, 130, n. 112; Petrushevsky 1960, 241. Villages: e.g., ĞT/Rawšan I, 88; II, 1221. Lands, parcels of lands, and movable possessions: e.g., line 4 of a decree among the Ardabīl documents (MMI, s.25883 (r.464); FABȘ, 118; PUM, Urkunde VII).

The examples of Ilkhan's $\bar{\imath} \check{g} \bar{u}$ will be discussed in detail later. For examples of $\bar{\imath}$ ğ $\bar{u}$ s of queens and princes (also princesses), see, e.g., ǦT/Rawšan II, 1445, 1509.
} 
$\bar{\imath} n g \bar{y}$ belonging to the Chinggisids (including Hülegüids) often appears in Persian sources, we scarcely find any other owners of $\bar{\imath} n g \bar{u}$ such as amīrs (M. noyan; commanders). ${ }^{8}$ Thus, the term $\bar{\imath} n \bar{g} \bar{u}$ was used mostly and especially for the private property of Ilkhan, other Hülegüids, and other Chinggisids.

Third, how did owners acquire their $\bar{i} n g \bar{u}$ ? A person's $\bar{i} g \check{g} \bar{u}$ was generally formed from $(\alpha)$ things taken from his father and $(\beta)$ what he personally acquired.

The Ğämi 'al-Tawārīh contains references to $\overline{i n g} \bar{u}(\alpha)$. It is reported in that source that Baraq (r. 1266-1271), a great-grandson of Čayatai, said in the spring of 667 AH/1269 CE that sons of Hülegü Qan, that is, his successor Abaya (P. Abāqā, r. 1266-1281) and his brothers, received

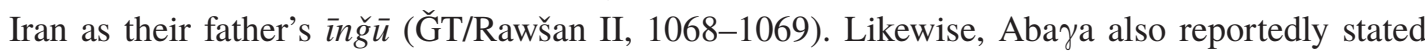
in 668/1269-70, “This land [i.e., Iran] was inherited from my father, and this is our $\bar{i} g \check{g}$. Today, we possess it by the sword" (ĞT/Rawšan II, 1071-1072). It seems unlikely that these reports of Baraq's and Abaya's statements reflect authentic situation at that time, since, as we will see in the next section, Baraq held his own $\bar{\imath} n \check{g} \bar{u}$ properties in Iran then. However, both statements demonstrate a commonly accepted norm in those days: A person's children could inherit their parent's $\bar{i} g \check{g} \bar{u}$ and make it their own $\overline{i n} \check{g} \bar{u}$.

Then, how did the owners personally acquire $\overline{i n} \check{g} \bar{u}(\beta)$ ? We find cases in which captives were made $\overline{i n g} \bar{u}$. For instance, according to the $\check{G} \bar{a} m i^{\star}$ al-Tawārīh, Sāli Noyan, the chief amīr of the tamma (garrison troops), when he conquered and plundered Kašmīr and Hindūstān, sent many captives from there to Hülegü, and they lived in $\bar{\imath} n \check{g} \bar{u}$ villages in the Ilkhanate (ĞT/Rawšan I, 88). It seems that those inhabitants of the $\bar{i} n \check{g} \bar{u}$ villages were also $\bar{i} n \check{g} \bar{u}$.

Moreover, it was not rare that people offered themselves, their families, or their private properties to the Ilkhan or other Hülegüids as $\bar{\imath} n g \bar{u}$, thereby making connections with them in the hope of their patronage.

For example, when Abaya Qan fought the army of Baraq in Hurāsān and put it to flight in 1270, the ruler of the Šabānkāra district, Ğalāl al-Dīn Ṭayyib Šāh (r. 1265-1276), joined Abaya's

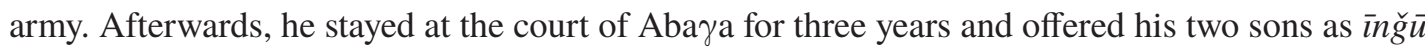

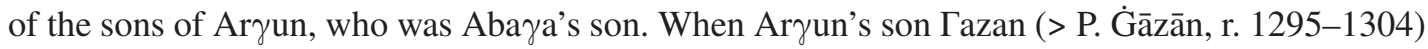
ascended to the throne of Ilkhan, he appointed Giiyās al-Dīn, one of the two sons of Ğalāl al-Dīn

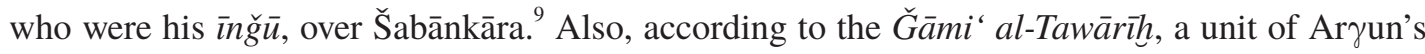
$\bar{i} n \bar{g} \bar{u}$ troops was formed during Abaya's reign, when each amìr (har amīr $\overline{\text { }}$ ) voluntarily offered

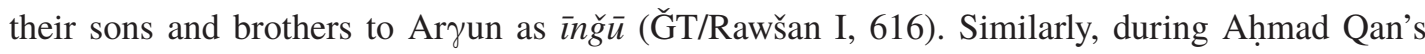

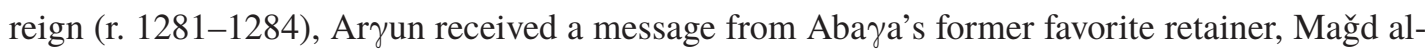
Mulk Yazdī, who impeached Aḥmad's financial minister (șāhib-dīwān), Šams al-Dīn Muhammad

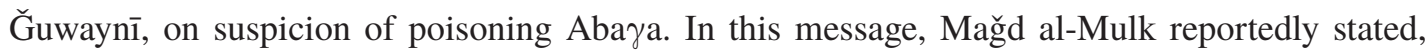

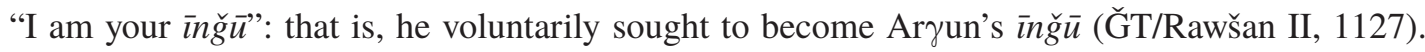
Furthermore, the Ğämi ‘ al-Tawārīh speaks of people in Iran giving their children to the Hülegüid

For a rare example of $\bar{\imath} n \check{g} \bar{u}$ s of $a m \bar{\imath} r$ s, see ĞT/Rawšan II, 1445.

9 MA, 177; Watabe 2007, 52. The Qa' an or the Ilkhan ordered the local rulers to offer their sons as hostages (Matsuda 1978; Matsuda 2002). This policy was similar to the practice of hostage (nawā) in Iran. When Hülegü conquered Šabānkāra, he demanded a son of the then ruler as nawā (MA, 165-166). The Salghurid atabegs of Fārs, the QutlughKhanid sulțāns of Kirmān, and the Saljuq sulțāns of Rūm let their sons or brothers stay at the court of the Qa'an or the Ilkhan (Takagi 2014a, 121, 123-126). 
queens, princes (also princesses), and amīrs as $\bar{\imath} n g \bar{u}$ or partner $(\bar{u} r t \bar{a} q \bar{\imath}) .{ }^{10}$

We also find cases in which people offered their private properties for conversion into the $\overline{i n g} \bar{u}$ of the Ilkhan and his family. For instance, Abiš Hātūn, the last Salghurid atabeg of Fārs and Hülegü's daughter-in-law, urged Ahmad Qan to turn the former private lands of the atabegs into $\bar{i} \bar{g} \bar{u}$. With his permission, and after receiving the authority to gain a part of revenues from the $\bar{i} \check{g} \breve{u}$, she converted many villages, cultivated lands, orchards, and parcels of land in Fārs into inğ $\bar{u}$ (TW, 211-212; Lambton 1988, 120; Watabe 1997, 192; Aigle 2005, 131). Likewise, around 679/1280-81, during Abaya's reign, Faḩr al-Dīn Ḥasan, a sayyid from Šīrāz, offered to convert

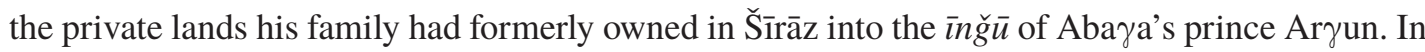
this case, although Abaya permitted the conversion, Aryun had to wait until his own enthronement before he could finally make the lands in question, along with many other real properties in Fārs, his $\bar{i} n \check{g} \bar{u}$ because of the opposition first of local governors of Šìrāz and then of Abaya's successor, Ahmad Qan (TW, 126, 230; FNN, 948-949). ${ }^{11}$ However, once the conversion was realized, a son of Fahr al-Dīn, Quṭb al-Dīn Ahmad, was appointed to administer the ìnğ $\bar{u}$ and to collect revenue from it (TW, 231; Lambton 1988, 121; Watabe 1997, 203; Aigle 2005, 137-138). Further, this

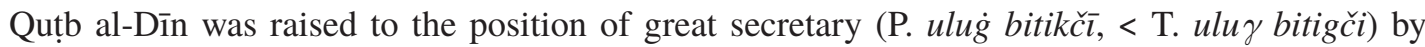
Aryun's son Гazan Qan (TW, 419; TG, 605; Watabe 1997, 203), who had acquired the inğ $\bar{u}$ lands

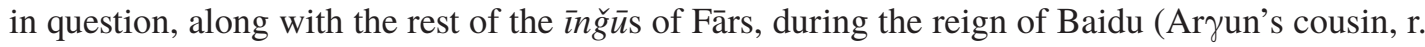
1295) (TW, 317-318; ĞT/Rawšan II, 1249).

These two cases, both pertaining to the formation of inğ $\bar{u}$ s in Fārs, indicate that landowners offered private lands of their family as $\bar{\imath} \grave{g} \bar{u}$ lands in order to establish connections with the then Ilkhan or his family. ${ }^{12}$ Quṭ al-Dīn's promotion to the position of the great secretary was no doubt a successful outcome of such a strategy. Also important is the fact that, in either case, it was a member of the family which had formerly owned the lands that was entrusted with the administration of or revenue collection from the same lands that were now turned into $\bar{i} n g \bar{u}$.

Finally, the Ğämi “al-Tawārīh indicates that the Qa'an or the Ilkhan sometimes gave subjects and lands to someone of his family as $\bar{i} n g \bar{u}$ of that person. ${ }^{13}$ For instance, Abaya Qan gave troops to his grandson Гazan as $\bar{\imath} n g ̆ \bar{u}$ (ĞT/Rawšan I, 616). It is also reported that a son of Činggis Qan, Ögödei Qa'an granted a province (wilāyat) in Transoxiana to his elder brother Čayatai as $\bar{\imath} n \bar{g} \bar{u}$ (ĞT/Rawšan I, 775).

The last question is the nature and the extent of influence and authority the owners wielded

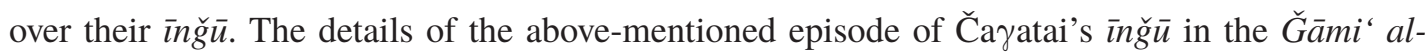
Tawārīh gives an answer to this question. The account tells that Ča

${ }^{10}$ ĞT/Rawšan II, 1445; Petrushevsky 1960, 241. The mention of amīrs in this account suggests the possibility that they also had their own $\bar{\imath} \bar{g} \breve{u}$ in the Ilkhanate, as mentioned earlier. On P. $\bar{u} r t \bar{q} q \sim u r t \bar{a} q(<$ T. ortuq, M. ortu $\gamma$ ), see TMEN II, Nr. 446; Moriyasu 1997. This term was broadly used in the sense of commercial partner of the Mongol rulers in those days (Moriyasu 1997).

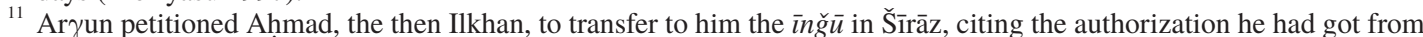
Abaya to convert the related lands, along with the regions (tūmānāt) of 'Irāq-i 'Ağam (see below for the status of 'Irāq-i

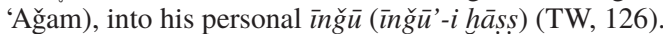

${ }^{12}$ To be exact, the related lands had first been placed under the control of the central dīwān before being converted into inğu.

${ }^{13}$ Lambton maintained that the term $\bar{\imath}$ ğ $\bar{u}$ referred to the persons or lands the Qa'an gave to his relatives and others (Lambton 1988, 118; cf. Schurmann 1956, 330). However, as shown here, not all the $\bar{\imath}$ ğ $\bar{u}$ was given by the Qa' an. 
the province in question to a person whose name or post is not known to us. Mahmūd Yalawači, who was responsible for the administration of the province, reported Ča

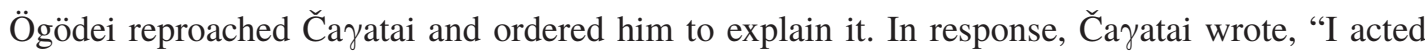
misguidedly without knowing it. I have nothing to write to you. However, since you ordered me

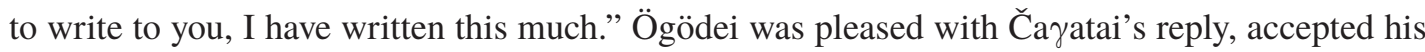
excuse, and then gave the province to him as his $\bar{\imath} n g ̆ \bar{u}$ (ĞT/Rawšan I, 775).

This episode shows that Ča $\breve{a t a i}$ had no authority to give, at his discretion, the provinces under the administration of Maḥmūd Yalawači to someone else (Kawamoto 2013, 179). It is unclear whether Ča the province was under the administration of Mahmūd Yalawači. In any case, Ögödei made this

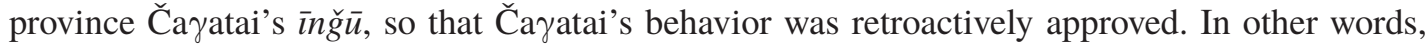
Čayatai gained the right to own this land and to give it to someone else. Whether this episode is historically true or not, it shows shared understanding in Ilkhanid Iran, where the $\check{G} \bar{a} m i$ ' $a l$ Tawārīh was compiled, that the owner of an $\overline{i n g} \bar{u}$ could dispose of it at his discretion.

Hence, briefly stated, the term $\bar{i} n \check{g} \bar{u}$ as appearing in the Persian sources from the Ilkhanid period mainly denoted private subjects and lands. The owners of $\bar{\imath} \check{g} \check{u} \bar{u}$ as appearing in the Persian sources were the Ilkhan, other Hülegüids, other Chinggisids, and sometimes amīrs. The general understanding was that they possessed the authority to hold onto or dispose of $\overline{i n g} \bar{u}$ at their discretion. The sources presuppose the following as the ways in which a person's $\bar{\imath}$ ğ $\bar{u}$ could be formed: inheritance from his father, his personal acquisitions (e.g., captives or booty), offerings from amīs, local rulers, or people, and gifts from the Qa'an or the Ilkhan.

\section{The $\bar{I}$ ğ $\bar{u}$ of the Ilkhan}

In the previous chapter, we examined different aspects of $\bar{i} \check{g} \bar{u}$ concept as appearing in the Persian sources from the Ilkhanid period. In this chapter, we will focus on Ilkhan's $\bar{i} g \bar{g} \bar{u}$. We will elucidate how Ilkhan's $\bar{\imath} n g \bar{u}$ in Iran came to be formed, how it was passed down through the generations, and how it was administered.

\section{The formation of Ilkhan's $\bar{\imath} n \bar{g} \bar{u}$ in Iran}

How the Ilkhan's inğ $\bar{u}$ in Iran was formed? As is well known, Batu Qan (d. 1256) and his son Berke Qan (r. 1257-1266) from the Jochids had great influence over parts of Iran during Hülegü's expedition. After Hülegü conquered Bag̀dād in 656/1258, Jochid princes, who had participated in the conquest, felt pride in their military exploits and complained that Hülegü ignored them. In those days, the local administrators and governors of Berke and his family, who had gained fertile districts in the provinces of Hुurāsān, 'Irāq-i 'Ağam, Āzarbāyǧān, Arrān, and Gurğistān, reportedly affirmed, "These districts are our $\bar{n} \bar{g} \breve{u}$ " (AM, 40; Takagi 2009, 145-146). This episode reveals that in these districts, which were practically subject to Berke and other Jochids, their officials claimed substantial property rights for the Jochids.

It is important to note that the provinces mentioned above were among the areas where Möngke Qa' an ordered a census in 1253 and allocated the lands and the inhabitants to the Chinggisids in 1256. ${ }^{14}$ In North China, Möngke took a census in 1252 . He decreed that parts of persons controlled 
independently by the Chinggisids to be placed under the control of the central government, thereby limiting those Chinggisids' authority over the people in question (Matsuda 1978; Matsuda 2002, 191-197; Matsuda 2013). This suggests that by conducting a similar census, Möngke tried to restrict the influence of related Chinggisids also in Iran. The above-mentioned claim by the administrators and governors affiliated with the Jochids therefore shows that the Jochids retained their authority over those provinces and owned them as inğ $\bar{u}$ or almost as $\bar{i} n \check{g} \bar{u}$ even after Möngke's attempt at curtailing their influence over them.

It is also reported that in 665/1266-67, Baraq and Qaidu of Ögödeids, dispatching an envoy,

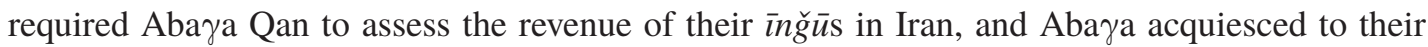
demands (ĞT/Rawšan II, 1063). Although the details of these $\bar{\imath} \check{g} \breve{u}$ s are unknown, at least some of Ča atai and Ögödei families held revenue-producing territories or subjects in Iran as their $\overline{i n g ̆} \bar{u}$, even early in Abaya's reign (Takagi 2009, 148-149).

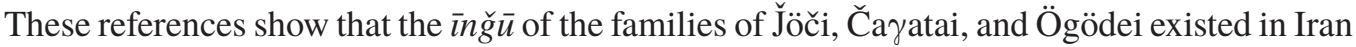
even after Möngke Qa'an's census. It appears, however, that through the time of political confusion following the sudden death of Möngke in 1259, Iran gradually came to be dominated by the Hülegüids as if it was their $\bar{i} n g \bar{u}$, although not all the Chinggisids agreed to their domination. ${ }^{15}$ The Jochid princes in Iran died inexplicably one after another, and the amīrs with troops dispatched by the Jochids fled Iran. Then, in 660/1261-62, a war between Hülegü and Berke broke out. Further, in 1270, the army of Baraq advanced into Hurāsān, and Abaya drove it away. Soon afterwards, Möngke's successor, Qubilai Qa'an approved Abaya's control of Iran (ǦT/Rawšan II, 1097). In this way, the influence of Jöči, Čayatai, and Ögödei families in Iran gradually fell. In contrast, remarkably, the $\bar{i} n \check{g} \bar{u}$ of the Hülegüids began to increase by degrees.

In the late 1270s, Abaya turned parts of the provinces conquered by Hülegü into inǧu. For instance, in 676/1277-78, Šams al-Dīn Ğuwayn̄̄, the financial minister of Abaya legally bought Arzanğān (Erzincan) and its dependencies in Rūm and ordered that they be added to the $\overline{i n g} \bar{g}$ and private lands (hăș̣a) of the Ilkhan (pādšāh) (AA, 620; Cahen 1968, 332-333; Itani 1985, 49).

Another case in point is the forfeiture of private lands and movable property belonging to the sultānn of the Qutlugh-Khanids in Kirmān, Muẓaffar al-Dīn Hağğāğ. He had departed for Delhi in 669/1270-71 as the result of a dispute with Qutluy-Terken, a widow of his deceased father. Aba $\mathrm{ya}$ ordered that Hağğăğ's properties be placed under the control of the ministry of private property

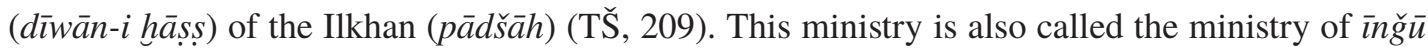

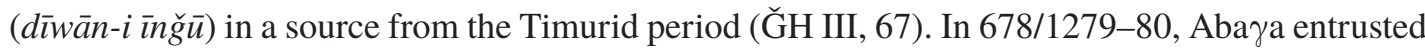
a brother of Hağğāğ, Ğalāl al-Dīn Suyūrgiatmīš, with administration of this $\bar{\imath} n g ̆ \bar{u} .{ }^{16}$

Likewise, in the province of Lesser Lurs, after Abaya executed the atabeg Tāğ al-Dīn Šāh in 677/1278-79, a son of the former atabeg Falak al-Dīn Hasan was appointed as the new atabeg and the governor of dalāy (hākim-i dalā) of the province. ${ }^{17}$ Simultaneously, his brother 'Izz al-Dīn

\footnotetext{
${ }^{14}$ On the census and allotment, see TĞ/Qazwīnī II, 255-258; YS, Ch. 3, 49; Honda 1967, 105-107; Allsen 1987, 130133; Allsen 2001, 177; Kawamoto 2013, 192-193.

${ }^{15}$ On this process, see Takagi 2009.

${ }^{16}$ TŠ, 209; SU, 50; ĞH III, 67. This entrustment was later temporarily withdrawn (SU, 51). In the Ilkhanid period, the private properties of dismissed or executed notables were confiscated and made the $\overline{i n g} \bar{u}$ of the Ilkhan (Petrushevsky 1968, 516; Lambton 1988, 120; Watabe 1997, 192; Aigle 2005, 151; Floor 2012, 107).

${ }^{17}$ The meanings of the term dalāy $\sim$ dala $\sim$ dala will be discussed in the third section of this chapter.
} 
Husayn became his heir and the governor of $\bar{\imath}$ ğ $\bar{u}$ of the province (TG, 558; Petrushevsky 1960, 242). It is possible that Abaya gained new $\bar{\imath} n g ̆ \bar{u}$ properties there and that 'Izz al-Dīn was appointed to administer them.

\section{The inheritance of Ilkhan's inğ $\bar{u}$}

Who inherited the Ilkhan's inğūs? As has been made clear above, the general understanding during the Ilkhanid period was that the $\bar{i} \bar{g} \bar{u}$ of a deceased person would be inherited by his sons. It is therefore interesting to observe that the general trend in the case of Ilkhan's $\bar{\imath} g \check{g} \bar{u}$ was apparently that the next Ilkhan would succeed to the ownership of the former Ilkhan's $\bar{\imath}$ ğ $\bar{u}$.

The Ğämi 'al-Tawārīh reports that all the troops dwelling in Iran and originated from Hülegü's

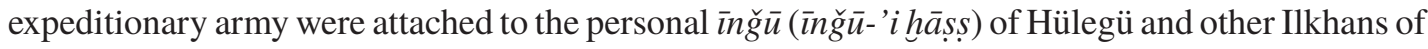
his family (ĞT/Rawšan I, 615-616). It is assumed that it is the successive Ilkhans Abaya (Hülegü's

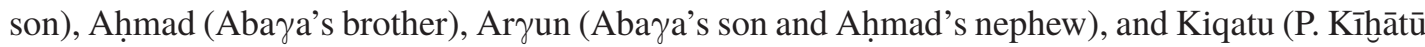
or Gayhātū, r. 1291-1295; Aryun's brother) that are meant here. ${ }^{18}$ Furthermore, we know that in the reign of Argun's son Гazan, these troops belonged to him (ĞT/Rawšan I, 616). This instance appears to indicate that the $\overline{i n g} \bar{u}$ army of an Ilkhan was inherited by the next Ilkhan. However, because of related texts' terseness, we cannot rule out the possibility that Hülegü's $\bar{\imath} g \check{g} \bar{u}$ army was inherited by the Ilkhans from Abaya to Tazan not because they were Ilkhans, but because they were Hülegü's descendants.

The case of the Qara'unas, a unit of ten thousand that formed a part of Hülegü's expeditionary army and originally garrisoned the provinces between Hurāsān and Kašmīr, helps us clarify the rationales behind the inheritance of the $\bar{i} n g \bar{u}$ army. We now focus on this unit and examine whom this unit followed through the generations. A part of the Qara' unas became Abaya's personal troops (hāsșa), when Abaya resided in Hurāsān during the reign of Hülegü. Probably during Aba ya's reign, Baġdād was designated as their winter quarters (ǦT/Rawšan II, 1131; Shimo 1995, 80-86; Takagi 2014b, 28). Later, Ahmad Qan appointed Tagacčar as their commander (TW, 115).

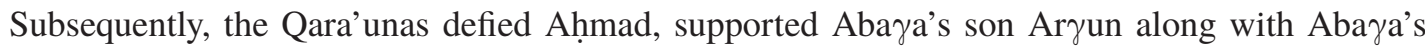

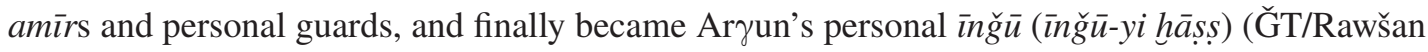
II, 1131, 1249; Takagi 2014b, 27). Still later, they followed another son of Abaya's, Kiqatu Qan, who changed their commander at his discretion (TW, 260). When Baidu rebelled against Kiqatu

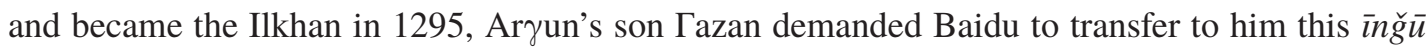

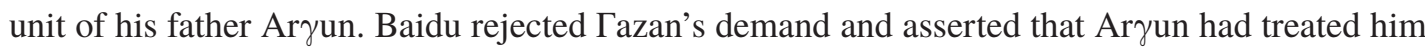
as a son and assigned Bağdād and Ṭagačar to him. Baidu claimed that since Ṭagačar and Qara'unas followed him due to the said arrangement by none other than Aryun, Гazan's father, the unit should continue to follow him (TW, 318; ǦT/Rawšan II, 1249).

\footnotetext{
${ }^{18}$ Baidu is not counted among the Ilkhans in the $\breve{G} \bar{a} m i$ ' al-Tawārīh (the work does not have a separate section for his reign). On another note, it appears doubtful if all the members of Hülegü's expeditionary army were Hülegü's $\bar{\imath} n g \check{u}$ as is claimed in the Ğâmi ‘ al-Tawārīh. The claim made in the Ğämi ‘ al-Tawärīh is that Möngke Qa'an designated the

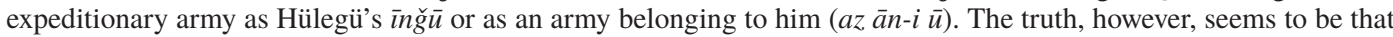
most of the related troops gradually came to establish a close relationship with Hülegü, the successive Ilkhans, and their family. The related accounts in the Ğämi 'al-Tawārīh clearly aim to justify the Ilkhanid control of the army in Iran, which originally consisted of the soldiers drafted from the troops under the Qa' an and various other Chinggisids (Takagi 2014b).
} 
Generally speaking, the Qara'unas were under the command of successive Ilkhans after Abaya, from Ahmad to Cazan. However, when we pay attention to the details, it becomes apparent that the Qara' unas also made moves that cannot be explained by the principle of Ilkhan-to-Ilkhan succession. First, the Qara' unas came to follow Abaya's son Aryun even during Ahmad's reign

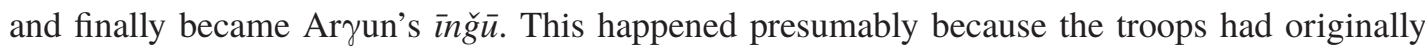
belonged to Abaya before Abaya's enthronement and they maintained a close connection with him. The assumption of the command of the Qara' unas by Kiqatu appears to be explainable by the same logic. Second, Гazan found himself entitled to demand the Qara' unas from Baidu. This can also be explained by the fact that his father Aryun had established relationships with the troops prior to his enthronement. In addition, the above statement of Baidu demonstrates that he also recognized that the sons or quasi-sons of Aryun had the right to control the troops in question.

The inheritance of Ilkhan's inğ $\bar{u}$ troops by his son can also be confirmed in an account in the Ğàmi 'al-Tawārīh that is not related to the Qara'unas. The account in question reports that $\Gamma$ azan

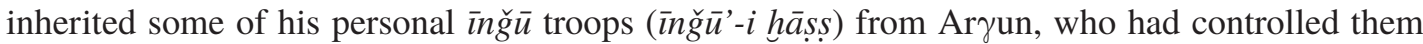

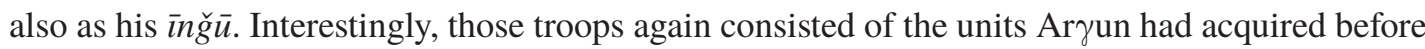

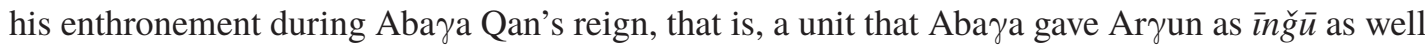
as another unit that was formed when amìrs voluntarily offered their sons and brothers to Aryun as $\bar{i} \check{g} \bar{u}$ (ĞT/Rawšan I, 616). It is thus confirmed that it was the timing of the acquirement by the deceased Ilkhan that decided whether the $\overline{i n g} \bar{u}$ troops of that Ilkhan would go to the next Ilkhan or to his sons.

Based on these examinations, we can now conclude that a new Ilkhan often acquired the former Ilkhan's $\bar{\imath} n g \bar{u}$ troops along with other military forces. It has been made clear, at the same time, that sons of the former Ilkhan could claim the right to inherit the $\bar{i} n \bar{g} \bar{u}$ army their father had acquired before his enthronement, although such claims were not always accepted by the new Ilkhan.

This observation appears to be applicable to the inheritance of the $\bar{i} n g \bar{u}$ properties that Abaya formed in Iran during his reign as well. The general rule, it appears, was that those properties be handed down by the successive Ilkhans. To begin with, it can safely be assumed that Abaya's successor Aḥmad gained those inğūs, since it is highly unlikely that he approved of Ar $\gamma$ un's authority over them. ${ }^{19}$ After Ahmad, most of the properties were probably inherited by Aryun, and then by Kiqatu. It can also be assumed that when Гazan became the Ilkhan, he acquired the properties in question. ${ }^{20}$ After Гazan, most of the $\bar{\imath}$ ğ $\bar{u}$ s under him seem to have gone to his brother Ölǰeitü (r. 1304-1316) and then to Ölǰeitü’s son Abū Sa‘̄id (r. 1316-1335), because the sons of Tazan had died in early life and his daughter Öly̌ei-Qutluy had married Abū Sa‘īd (ĞT/Rawšan II,

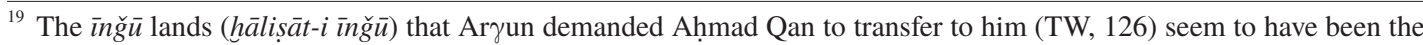
inğ $\bar{u}$ s formed during Abaya's reign. Ahmad, who had stayed in Mongolia during Hülegü's expeditions and arrived in Iran as late as early in Abaya's reign, was reputedly envious of Abaya's throne from the beginning (AM, 46). After his enthronement, Ahmad took hostile attitudes towards Aryun, who also remained defiant towards him. Ahmad

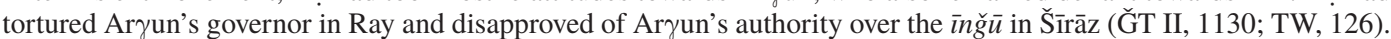
Furthermore, before the war with Argun in 683/1284, he captured several of Abaya's ex-attendants who supported

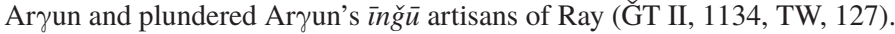

${ }^{20}$ Tazan's acquisition of the $\bar{\imath} n \grave{g} \bar{u}$ s in Fārs during Baidu's reign should be regarded as an exceptional case, as we will see shortly.
} 
1215; MAŠ, 78a, 78b).

There is, at the same time, an interesting case which indicates that the properties acquired by an Ilkhan before his enthronement were supposed to go to his descendants. When Cazan made the aforementioned demand on Baidu to hand over the Qara'unas, his demand also included the handover of the ìnğ $\bar{s}$ in Fārs and 'Irāq-i 'Ağam, which had formerly belonged to his father Aryun. What grabs our attention here is that while Baidu refused the handover of the Qara' unas, he consented to the handover of Fārs and most of 'Irāq-i 'Ağam where Arzun's inğ $\bar{u}$ s existed (TW, 318-319; ĞT/Rawšan II, 1249; cf. TW, 317). As for the $\bar{\imath} n g ̆ \bar{u}$ in Fārs, we already saw in the previous chapter that the conversion of related properties into Aryun's inğ $\bar{u}$ had been approved by Abaya during the latter's reign, although Aryun had to wait until his own enthronement to

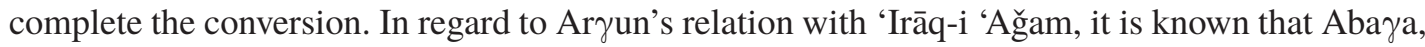
during his reign, gave to Aryun Malik Faḩr al-Dīn (malik rā pidaram ba man dāda) who seems to have been the governor of Ray at that time and that Aryun had his own $\bar{i} n \bar{g} \bar{u}$ artisans in Ray during Ahmad's reign. ${ }^{21}$ Thus, it is highly probable that Baidu had to accept Tazan's demand pertaining

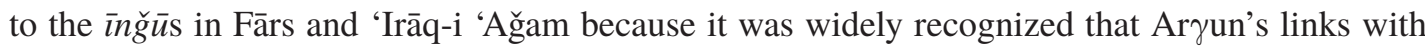
those properties dated back to the period prior to his enthronement.

\section{The administration of Ilkhan's $\bar{\imath}$ ğ $\bar{u}$}

Who administered the $\bar{i} n \check{g} \bar{u}$ of Ilkhan? In the narrative sources, we can find the names of six amirs to whom Abaya and the four Ilkhans descended from him delegated the administration of $\overline{i n g} \bar{u} \mathrm{~s}$ in provinces of Iran. Those six amīrs are: Altāğù Aqa from the Baryut tribe during Abaya's reign (ĞT/Rawšan II, 1061; Shimo 1995, 240; PUM, 71); Buqa from the J̌alayir tribes and then Ṭagačar from the Suqanut-Ba'arin tribe during Aryun's reign (ǦT/Rawšan II, 1167; TW, 231; Lambton 1987, 107; Shimo 1995, 245; PUM, 71; Aigle 2005, 137); Taiču during Kiqatu's reign; ${ }^{22}$ Satilmiš

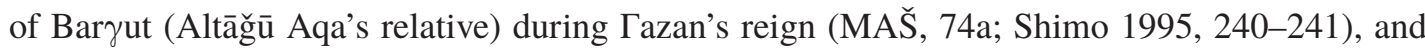
Amīr Ḥusayn from the J̌alayir tribes during Ölǰeitü's reign (TW, 471; PUM, 71; Shimo 1995, 168).

Although it is naturally assumed that the $\bar{i} n \bar{g} \bar{u}$ mentioned in the narrative sources were the Ilkhan's, those sources unfortunately do not specify whose inğ $\bar{u}$ s they are referring to. Ardabīl documents turn out to be helpful here. It is stated in one of them, that is, Amīr Husayn's decree of 704/1305 (MMI, s.25883 (r.464); FABȘ, 118; PUM, Urkunde VII; ȘM, 175-176; Aubin 1975-76, 95-96), that Husayn was entrusted with the inspection of $\bar{i} n g \bar{u}$ that consisted of lands, parcels of lands, and movable possessions ( $a m l \bar{a} k$ wa ašq $\bar{a} s$ wa $a s b \bar{a} b-i \overline{i n g} \bar{u})$ by the edict of Öly̆eitü (PUM, 84). Evidently, lines 4-6 in this document are referring to Husayn's position as the administrator of the $\bar{i} \bar{g} \bar{u}$ s in the provinces of Iran mentioned in the narrative sources. What we have to note here is the fact that the term $\bar{i} \bar{g} \bar{u}$ here is written outside the text of the document, on the extreme right margin of the paper, while a space is left blank within the line, where the word should be read, to show its location. This manner of writing was commonly used when the titles and names of the Ilkhans, their queens, princes (also princesses), and amīrs were mentioned or when the things

${ }^{21}$ ĞT/Rawšan II, 1130, 1134; also see note 11 above.

22 TS, 180; Lambton 1987, 107; Lambton 1988, 121; PUM, 71. Amīr Hasan from the Jalayir tribes may also have administered $\bar{\imath} \bar{g} \breve{u}$ during Kiqatu's reign (TW, 265; Shimo 1995, 166, 191). Taiču was dismissed in 692/1292-93, when $\overline{\text { inğ}} \bar{u}$ was integrated into dalāy as will be discussed below (TW, 268). 
related to the Ilkhans were referred to in the Ilkhanid documents. ${ }^{23}$ Thus, the document clearly

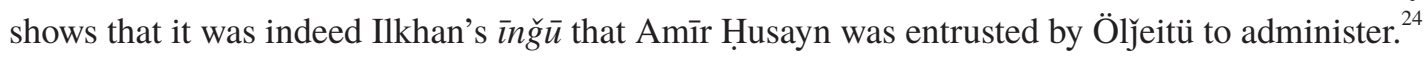

Another document from Ardabīl, the Persian decree of Amīr Tāyfū issued in 700/1301, refers to the great amīrs (umarā-yi kibār) as the governors (hukkām) of $\bar{i} \bar{g} \bar{u}$ (MMI, s.25859 (r.440); PUM, Urkunde IV). Also in this document, the text in line 8 is disposed in such a way that the term $\bar{i} \check{g} \bar{u}$ in line 9 would come to the head of the line. This suggests that the $\bar{i} \bar{g} \bar{u}$ referred to in this document also belongs to the Ilkhan. These great amirs may be identical with the amirs in charge of the $\bar{\imath} n g \bar{u}$ mentioned above, although it may also be possible that the term only denotes local officials who were entrusted with the administration of the $\bar{i} \bar{g} \bar{u}$ s in and around Ardabīl. ${ }^{25}$

Whether the $\bar{i} n \bar{g} \bar{u}$ s of Ilkhan were under the administration of the supreme dīwān or a special ministry remains incompletely understood (Hinz 1950, 137; Barthold 1951, 259; Petrushevsky 1960, 242; Petrushevsky 1968, 516; Togan 1981, 238; Lambton 1988, 121; PUM, 71). In some

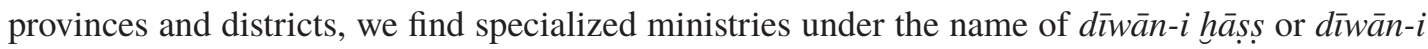

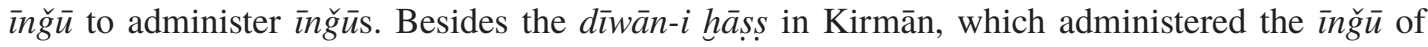
Ilkhan there as mentioned earlier, we find in the sources references to the dīwān-i inğ $\bar{u}$ in Fārs (TW, 231; Petrushevsky 1960, 243), the dìwān-i ìnğ in in Rūm (TS, 228), and the dīwān al-īnğ $\bar{u}$ alSăhibì in Yazd of 'Irāq-i 'A ğam. ${ }^{26}$ If the village confirmed as non-īnğ $\bar{u}$ land by the supreme dīwān in the decree of 726/1326 (SAMI, s.250) is to be located in Fārs, the dīwān-i ing ğ $\bar{u}$ mentioned in the decree will probably denote the dīwān-i ìnğ $\bar{u}$ of Fārs. ${ }^{27}$

An important question pertaining to the administration of the $\bar{i} n \bar{g} \bar{u}$ is relations between the $\bar{\imath} n g \bar{u}$ and the dalāy. The term dalāy $\sim$ dala $\sim$ dala appears as distinguished from the $\bar{\imath}$ ğ $\bar{u}$ of Ilkhan in Persian chronicles. This term is derived from the Mongolian term dalai, "ocean; sea; great lake; much; many; in great number or quantity; universal; great" (TMEN I, Nr. 196; Lessing 1960, 224). According to an account pertaining to Möngke Qa'an's reign in the Tārīh-i Wașsāf, eight thousand of the inhabitants of Buhārā were called the dalāy-i buzurg "the great dalāy," the subjects (hāsṣa) belonging to the successive Qa'ans from the Chinggisids (TW, 51). Previous studies have made clear, however, that in the Ilkhanate the term came to denote the dīwāni property administered by the supreme $d \bar{l} w \bar{a} n$ : that is, the term signified state lands. ${ }^{28}$

\footnotetext{
${ }^{23}$ Fragner 1999, 287; PUM, 21-22. For an actual example of that practice, see the appendix of Šayh al-Hukamā’’’’s article in this volume.

${ }^{24}$ Gottfried Herrmann, who studied the same document, also expressed his opinion that Amīr Husayn was administering Ilkhan's $\bar{\imath} \check{g} \bar{u}$ (PUM, 71). He does not clearly state his evidence, although it appears he is also based on the same observation as stated here.

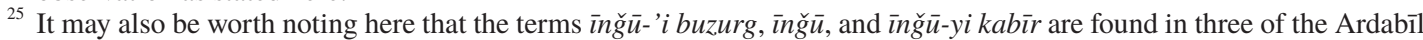
documents published to the date (İnğ $\bar{u}$ '’ $i$ buzurg: Amīr Tãyfū's decree of 700/1301 [MMI, s.25859 (r.440); FABS, 113-114; PUM, Urkunde IV]. Inğū: Amīr Husayn's decree of 704/1305 [MMI, s.25883 (r.464); FABȘ, 118; PUM, Urkunde VII; ȘM, 175-176; Aubin 1975-76, 95-96]. Inğ $\bar{u}-y i$ kabìr: the decree of 725/1325 [MMI, s.25884 (r.465); FABȘ, 118; Herrmann and Doerfer 1975]). The adjective with the meaning "great" (e.g., P. buzurg or A. kabīr) was often used in Persian sources to describe something or someone related to or belonging to the Qa'an or the Qan from the Chinggisids, that is, mostly the Ilkhan in the case of Iran, out of respect for them (Shimo 1995, 455-475). Thus, it is highly probable that the $\bar{i} n g \bar{u} \bar{s}$ mentioned in those documents belonged to the reigning Ilkhans at their respective issue dates, that is, Гazan, Öly̌eitü, and Abū Sa‘īid.

${ }^{26}$ This ministry administered the private properties formerly owned by șạhib al-dīwān Bahā' al-Dīn, a son of Šams al-Dīn Ğuwaynī (YY II, 496).

${ }^{27}$ See Šayh al-Hukamā'`’’s article in this volume.

${ }^{28}$ Minorsky 1943, 25; Schurmann 1956, 330; Honda 1959, 44; TMEN I, Nr. 196; Togan 1981, 238; Floor 2012, 107. The term dalāy was sometimes used instead of the term dīwānī (ĞT/Rawšan II, 1481).
} 
In Rūm during Tazan's reign, we find the ministry of dalāy (dīwān-i dalāy) and its two

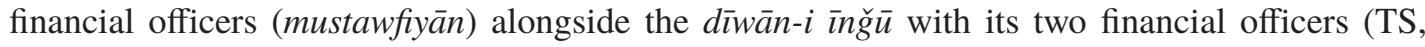
228). Similarly, two posts of governor of dalāy and governor of $\bar{\imath} \bar{g} \bar{u}$ existed in Lesser Lurs, as shown in the previous section. ${ }^{29}$

Two categories of properties, however, could sometimes be administered together. The policy of integrating $\bar{\imath} n g \bar{u}$ into dalāy was temporarily adopted all over Iran in 692/1292-93, during Kiqatu's reign. Both in Rūm and in Fārs, for example, an official was appointed in that year to administer dalāy and $\bar{\imath} \check{g} \breve{u}$ (TS, 180; TW, 268). We also find a unique reference to the ministry

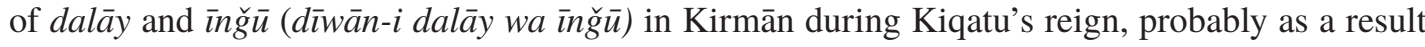
of the aforementioned policy (SU, 64). Likewise, the Muršid fi al-Hisāb, an accounting manual compiled in Persian during Kiqatu's reign, suggests that tax revenues from the $\bar{i} n g \bar{u}$ lands ( $\dot{z} i y \bar{a}^{\prime}-i$ inğ $\bar{u} \bar{l} y a$ ) in the districts of 'Irāq-i 'Ağam were administered together with the taxes collected and administered by the supreme $d \bar{l} w \bar{a} n$, in those days (MH, 103a-106a; Watabe 2011, 27, n. 34).

Finally, it can be understood that most of $\bar{i} \bar{g} \breve{u}$ s were recorded in the ledgers of $\bar{i} \bar{g} \bar{u}$ (dafātir-i $\overline{i n g} \bar{u}$ ) by the end of 704/1305 at the latest, since Amīr Husayn refers to some of those ledgers in his decree, dated Dū al-Ḥiğğa 704/1305. ${ }^{30}$ According to the decree, these ledgers stated that two villages, a garden, and a cultivated plot were confirmed as the private property of Kamāl al-Dīn Huwāğa Aqūtīn in the official surveys conducted during Aryun's reign. Also, in Fārs during the reign

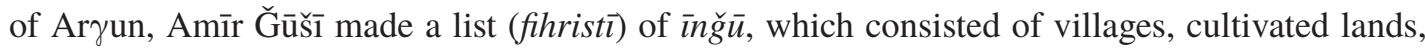
water resources, mills, and irrigated and rain-fed lands (TW, 228; Lambton 1988, 121; Watabe 1997, 193; Aigle 2005, 141). Thus, at least the $\bar{\imath}$ ğ $\bar{u}$ s of several provinces seem to have been

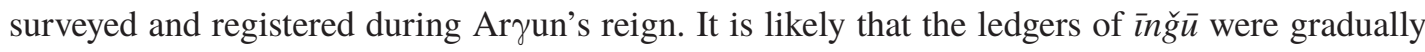
compiled later, based on these lists of $\bar{\imath} n \bar{g} \bar{u}$ s $(\mathrm{TW}, 56)$.

\section{Conclusion}

The term $\bar{i} n g \breve{u}$ as appearing in the Persian sources from the Ilkhanid period mainly refers to the private lands and subjects of the Ilkhan, other Hüleguiids, or other Chinggisids. During Abaya Qan's reign, the families of J̌öči, Ča yatai, and Ögödei gradually reduced their influence on Iran. In contrast, in the late 1270s, Abaya Qan formed his own $\bar{\imath} n \bar{g} \bar{u}$ s in the provinces. The $\bar{\imath} n \bar{g} \bar{u}$ of an Ilkhan was inherited by the next Ilkhan, although the sons of the deceased Ilkhan could demand that part of their father's $\bar{\imath} n g \bar{u}$ that he had acquired before his enthronement. Further, at least Abaya and the four Ilkhans descended from him appointed specific amīrs to administer their $\bar{i} n \bar{g} \bar{u}$. Special ministries (or/and governors) of $\bar{\imath} n g \bar{g} \bar{u}$ existed in some provinces and districts. In contrast, dalāy or dīwānī properties were administered by the supreme dīwān.

Before closing the paper, it appears interesting to note that the general understanding attested in the Persian sources that a person's $\bar{i} n g \bar{u}$ would be inherited by his children can also be attested

\footnotetext{
${ }^{29}$ During the reign of Ölǰeitü, the then atabeg Badr al-Dīn Mas 'ūd was appointed to the governorship of dalāy in Lesser Lurs, while his cousin 'Izz al-Dīn Muhammad was appointed to the governorship of $\bar{\imath}$ ğ $\bar{u}$ there. Afterwards, the latter was entrusted with the administration of both dalāy and $\bar{i} g \check{g} \bar{u}$ (TG, 560).

${ }^{30}$ PUM, 85. Hamd Allāh Mustawfī also refers to the ledgers of $\bar{\imath} \check{g} \bar{u}$ districts (dafātir-i bulūk-i $\left.\bar{\imath} \bar{g} \breve{u}\right)$ in NQ I, 84. Further, the ledgers (dafātir) in line 5 of the decree SAMI, s.250 probably refer to the ledgers of $\bar{\imath} n g \check{u} \bar{u}$ (see Šayh al-Hukamā'-’’s article in this volume).
} 
in the Secret History of the Mongols, an earlier source in which the term appears in its original form emčü (SH/Kuribayashi, 442-445; SH/de Rachewiltz, 153). It is therefore possible that we are witnessing in the Ilkhan-to-Ilkhan succession a new development in the history of emčü/ $\bar{i} \check{g} \bar{u}$. We need further studies, however, to ascertain whether this conjecture is correct and, more importantly, whether the Ilkhan-to-Ilkhan succession mirrored the elevation of the position of the Ilkhan vis-à-vis his close relatives.

Needless to say, further inquiries are necessary for us to fully understand the $\bar{i} n \bar{g} \bar{u}$ in Ilkhanid Iran. The tasks awaiting us include, in addition to the preparation of a list of $\bar{i} n g \bar{u}$ areas throughout Iran, the elucidation of the difference between $\bar{i} n \check{g} \bar{u}$ and share (A. hiș̣a; P. baȟ̌s; M. qubi) of property, of the management of the revenues from $\bar{\imath}$ ğ $\bar{u}$ with special reference to the Ilkhan's private treasury, ${ }^{31}$ of the purpose of integrating $\bar{i} n g \bar{u}$ into dalāy during Kiqatu's reign (TW, 268) and probably also during Abū Sa ‘īd's reign (ŠN, 101), of the background for Гazan's decision to convert parts of his $\overline{i n g} \bar{u}$ properties into waqf (endowment) properties for his sons (ĞT/Rawšan II, 1590), and of the situation of $\bar{i} \bar{g} \bar{u}$ after the decline of the Ilkhanate.

\section{Bibliography and Abbreviations}

AA = Ibn Bībī, al-Awāmir al- 'Alā' '̄ya fì al-Umūr al-'Alā'̄yya, ed. by, Ž. Muttahiddīn, Tihrān, 1390 AHS.

Aigle, D. 2005: Le Fārs sous la domination mongole: politique et fiscalité (XIII'-XIV s.), Paris.

Allsen, T. T. 1987: Mongol Imperialism: The Policies of the Grand Qan Möngke in China, Russia and the Islamic Lands, Berkeley and Los Angeles.

Allsen, T. T. 2001: "Sharing out the Empire: Apportioned Land under the Mongols," in A. M. Khazanov and A. Wink (eds.), Nomads in the Sedentary World, Richmond, 172-190.

$\mathrm{AM}=$ Anon., Ahbār-i Muğūlān dar Anbāna-yi Quṭb, ed. by Ī. Af̌̃ār, Qum, 1389 AHS.

Aubin, J. 1975-76: “La propriéte foncière en Azerbaydjan sous les Ilkhans," Le Monde iranien et l'Islam 4, 79-132.

Barthold, W. 1951: "Die persische Inschrift an der Mauer der Manūčehr-Moschee zu Ani,” trans. by W. Hinz, Zeitschrift der Deutschen Morgenländischen Gesellschaft 101, 241-269.

Buell, P. D. 2003: Historical Dictionary of the Mongol World Empire, Lanham, Maryland, and Oxford.

Cahen, C. 1968: Pre-Ottoman Turkey: A General Survey of the Material and Spiritual Culture and History c. 1071-1330, trans. by J. Jones-Williams, London.

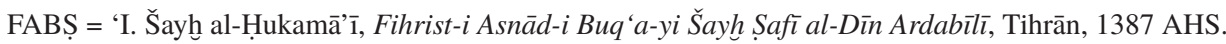

Floor, W. 2012: "KĀṢȘA,” Encyclopaedia Iranica, vol. 16, 106-112.

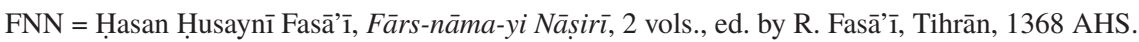

Fragner, B. G. 1999: "FARMĀN,” Encyclopadia Iranica, vol. 9, 282-295.

Gong, H. 2009: “Emčü and Its Related Issues in the Mongolian-Yuan Dynasty,” Xibei minzu yanjiu 60, 42-62 (in Chinese with English abstract).

ĞH = Ḥāfiz-i Abrū, Ğugrrāfiyā-yi Hāafiz-i Abrū, vol. 3, ed. by Ṣ. Sağğādī, Tihrān, 1378 AHS.

ĞT/Blochet = Rašīd al-Dīn Fażl Allāh Hamadān̄̄, Histoire des Mongols par Rashid el-din, ed. by E. Blochet, Paris, 1911.

ĞT/Quatremère = Rašīd al-Dīn Fażl Allāh Hamadān̄̄, Histoire des Mongols de la Perse, ed. by É. Quatremère, Paris, 1836, repr. in Amsterdam, 1968.

ĞT/Rawšan = Rašīd al-Dīn Fażl Allāh Hamadānī, Ğāmi ‘ al-Tawārīh, ed. by M. Rawšan and M. Mūsawī, 4 vols., Tihrān, 1373 AHS.

\footnotetext{
${ }^{31}$ For instance, early in Гazan's reign, a certain amount from the annual revenue from $\bar{\imath} n \bar{g} \bar{u}$ properties was given as stipends (idrār), endowment (waqf), charity (sadaqa), and reward (in ' $\bar{a} m$ ) to the "amīrs, commoners and the noble, the rich and the poor, and soldiers" (umarā wa waż̀ “ wa šarîf wa tawāngar wa darwī̌s wa laškarî̀) who gathered at annual qurirtais (assemblies) (ĞT/Rawšan II, 1385; Lambton 1988, 119). Afterwards, Гazan apportioned revenue from parts

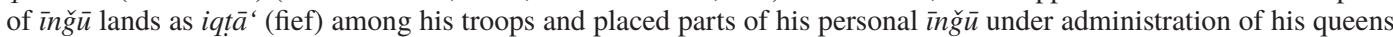
(ǦT/Rawšan II, 1381, 1508; Lambton 1988, 123-124).
} 
Herrmann, G., and G. Doerfer 1975: "Ein persisch-mongolischer Erlaß aus dem Jahr 725/1325,” Zeitschrift der Deutschen Morgenländischen Gesellschaft 125, 317-346.

Hinz, W. 1950: "Das Rechnungswesen orientalischer Reichsfinazämter im Mittelalter," Zeitschrift der Geschichte und Kultur des Islamischen Orients 29, 1-29 and 113-141.

Honda, M. 1959: "On the iqtāa (Military Fief) in Iran under the Mongol Domination,” The Annual Reports on Cultural Science (Hokkaido University) 7, 35-54, repr. in Honda 1991, 233-260 (in Japanese with English abstract).

Honda, M. 1967: “Early Mongol Administration in Iran,” Hoppō bunka kenkyū 2, 89-110, repr. in Honda 1991, 101-126 (in Japanese).

Honda, M. 1991: Historical Studies in the Mongol Period, Tokyo (in Japanese).

Itani, K. 1985: “The Ilkhanate and Rūm,” The World of Islam 23-24, 34-54 (in Japanese with English abstract).

Kawamoto, M. 2013: Mongol teikoku no guntai to sensō, Tokyo.

Lambton, A. K. S. 1987: “Mongol Fiscal Administration in Persia (Part II),” Studia Islamica 65, 97-123.

Lambton, A. K. S. 1988: Continuity and Change in Medieval Persia, New York.

Lessing, F. D. 1960: Mongolian-English Dictionary, Berkeley, CA, Los Angeles, and London.

MA = Muḥammad b. 'Alī Šabānkāra'1̄, Mağma' al-Ansāb, ed. by M. Muhaddis, Tihrān, 1363 AHS.

MAŠ = Anon., Mu 'izz al-Ansāb fǐ Šağarat Salāțīn Muğūl, MS. Bibliothèque Nationale, Ancien fonds, Persan 67.

Matsuda, K. 1978: “The Ruling System of Mongol in North China,” Machikaneyama Ronsō 11, 33-54 (in Japanese with English abstract).

Matsuda, K. 2002: "Mongol teikoku ni okeru kōshō no kakuho to kanri no shosō," in K. Matsuda (ed.), Research on Political and Economic Systems under Mongol Rule, Report of the Scientific Research Project, Grant-in-Aid JSPS, Basic Research (B), Osaka, 171-199 (in Japanese).

Matsuda, K. 2013: “Tōkaryō,” in T. Okamoto (ed.), Economic History of China, Nagoya, 173-174 (in Japanese).

MḤ = al-Ḥasan b. 'Alī, Muršid fī al-Hisāả, MS. Kitābhāna-yi Majlis-i Šūrā-yi Islāmī, no. 2154.

Minorsky, V. 1943: "Introduction” in Anon., Tadhkirat al-Mulūk: A Manual of Safavid Administration (circa 1137/1925), trans. by V. Minorsky, Cambridge, 5-36.

MMI = Mūza-yi Millī-yi İrān (National Museum of Iran).

Moriyasu, T. 1997: “Uigur Merchants on the Silk Road,” in Iwanami Kōza World History, vol. 11, Tokyo, 93-119.

Moriyasu, T. 2004: Die Geschichte des uigurischen Manichäismus an der Seidenstraße, trans. by Chr. Steineck, Wiesbaden.

Murakami, M. 1951: “Genchōhishi ni arawareta Ömčü no imi ni tsuite,” in Wada Hakushi Kanreki Kinen Tōyōshi Ronsō, Tokyo, 703-716.

NQ = Hamd Allāh Mustawfī Qazwīn̄i, The Geographical Part of the Nuzhat-al-Qulūb, ed. and trans. by G. Le Strange, 2 vols., Leiden and London, 1915.

Petrushevsky, I. P. 1960: Zemledelie i agrarnye otnošenija v Irane XIII-XIV vekov, Moscow.

Petrushevsky, I. P. 1968: “The Socio-Economic Condition of Iran under the Il-Khāns,” in J. A. Boyle (ed.), Cambridge History of Iran, vol. 5, Cambridge, 483-537.

PUM = G. Herrmann, Persische Urkunden der Mongolenzeit, Wiesbaden, 2004.

SAMI = Sāzmān-i Asnād wa Kitābhāna-yi Millī-yi Īrān (National Library and Archives of the Islamic Republic of Iran).

Schurmann, H. F. 1956: "Mongolian Tributary Practices of the Thirteenth Century," Harvard Journal of Asiatic Studies 19/3-4, 304-389.

ṢM = Zayn al-'Ābidīn 'Abdī, Sarīh al-Milk, ed. by M. Hidāyatī, Tihrān, 1390 AHS.

SH/de Rachewiltz = Anon., The Secret History of the Mongols, 3 vols., trans. by I. de Rachewiltz, Leiden, 2006 and 2013.

$\mathrm{SH} /$ Kuribayashi $=\mathrm{H}$. Kuribayashi and Choijinjab, Word- and Suffix-Index to the Secret History of the Mongols, Sendai, 2001.

Shimo, H. 1995: The Political Structure of the Mongol Empire: The Core Tribes of the Ilkhanid, Tokyo (in Japanese).

Shiraiwa, K. 1988: “İNJŪ in the Jāmi “ al-Tavārīkh of Rashīd al-Dīn,” Acta Orientalia Academiae Scientiarum Hungaricae 42/2-3, 371-376.

ŠN = Mu ‘īn al-Dīn Aḥmad Šīrāzī, Šìrāz-nāma, ed. by I. W. Ǧawādī, Tihrān, 1350 AHS.

Spuler, B. 1985: Die Mongolen in Iran: Politik, Verwaltung und Kultur der Ilchanzeit 1220-1350, Leiden.

SU = Nāṣir al-Dīn Munšī Kirmānī, Simt al- 'Ulā lil-Hażrat al- 'Ulyā, ed. by 'A. Iqbāl, Tihrān, 1328 AHS. 
Takagi, S. 2009: “The Mongol Royal Family's Authority and Private Property in Iran under the Hülegü’s Expedition," Shiteki 31, 133-156 (in Japanese).

Takagi, S. 2011: "Akhbār-i Mughūlān as a Source of Early Ilkhanid History," Journal of Asian and African Studies 82, 95-143 (in Japanese with English abstract).

Takagi, S. 2014a: “Two Dīwāns: Surveying the Reign of İān Zamīn in the Early Ilkhanids,” Tagen bunka 3, 111-158 (in Japanese with English abstract).

Takagi, S. 2014b: “Composition and Attribution of Troops under Hülegü Khan's Command,” Inner Asian Studies 29, 17-42 (in Japanese with English abstract).

TG = Hamd Allāh Mustawfī, Tārīh-i Guzìda, ed. by 'A. Nawā’̀̄, Tihrān, 1339 AHS, repr. in 1362 AHS.

TĞ/Qazwinī = 'Alā' al-Dīn 'Ațā Malik Ğuwayn̄̄, Tārīh-i Ğahāngušāy, 3 vols., ed. by M. Qazwīnī, Leiden, 1911.

TMEN = G. Doerfer, Türkische und mongolische Elemente im Neupersischen, 4 vols., Wiesbaden, 1963-1975.

Togan, Z. 1981: Umumî Türk Tarihine Giriş, 1946, 3rd ed., İstanbul.

TS = Karīm al-Dīn Mạ̣mūd b. Muhammad Āqsarā'̄̄, Müsâmeret ül-Ahbâr: mogollar zamanında Türkiye Selçukluları tarihi, ed. by O. Turan, Ankara, 1944.

TŠ = Anon., Tārīh-i Šāhī, ed. by M. Bāstānī Pārīzī, Tihrān, 2535 Š.

TW = Šihāb al-Dīn 'Abd Allāh Šīrāzī, Tağziyat al-Amșār wa Tazğiyat al-A 'ṣār (Tārīhn-i Waṣsāf), ed. by M. M. Iṣfahānī, Bombay, 1853, repr. in Tihrān, 1338 AHS.

Watabe, R. 1997: "The Local Administration of the Ilkhanid Dynasty: A Case of Fārs," Annals of the Japan Association for Middle East Studies 12, 185-216 (in Japanese with English abstract).

Watabe, R. 2007: "A Description of the History of Shabānkāras in the Daftar-i Dilgushā: A Study on Persian Verse Historiography (tārīkh-i manzūma) as a Historical Material of the Mongol Period," The Journal of Sophia Asian Studies 25, 49-80 (in Japanese with English abstract).

Watabe, R. 2011: "Murshid fī al-Hisāb: A Persian Accounting Manual in the Thirteenth Century Iran under Mongol Rule," in Y. Takamatsu (ed.), The Pervasion of Persian Bookkeeping in the Islamic World, Tokyo, 9-35 (in Japanese).

YS = Song Lian, Yuan-shi, Beijing, 1976.

YY = İ. Afšār, Yādgār-hāa-yi Yazd, vol. 2, Tihrān, 1374 AHS.

\section{Acknowledgement}

I am most grateful to the members of National Museum of Iran for kindly granting permission for our research. The research for this work was supported by grants-in-aid from the Toyota Foundation (Research Program D09-ID-043), the Mishima Kaiun Memorial Foundation in 2013, and JSPS KAKENHI Grant Number 25770260. 